\title{
Factors affecting the success of conservative management in de Quervain cases
}

\author{
De Quervain olgularında konservatif tedavi başarısını etkileyen faktörler
}

\section{Hasan Hüseyin Ceylan ${ }^{1}$, Özcan Kaya ${ }^{2}$, Barış Çaypınar ${ }^{3}$, Muhammed Beşir Öztürk ${ }^{4}$}

\begin{abstract}
Aim: De Quervain's disease, which is known as tenosynovitis of the first radial dorsal compartment, usually is a self-limiting condition and it could be managed conservatively. In this study, we aimed to evaluate the factors affecting the success of the conservative treatment.

Methods: Patients who admitted to outpatient service with radial styloid pain and diagnosed as de Quervain's disease between March 2014 and December 2016 were enrolled to our study. A total number of 84 patients evaluated retrospectively, and 12 of them excluded due to inadequate patient information, previous interventions in other clinics, and lost to follow up. Patients' files with regard to the patients' data on age, sex, duration of symptomatic period, history of previous trauma, season of admission and need of surgery were evaluated.

Results: Mean age of the patients was 42.24 (range 16-66) years. Of the cohort, 58 patients ( $80.6 \%$ ) were female and the remaining patients (19.4\%) were male. Mean length of pre-admission symptomatic period was 2.2 (range 1-12) months. There was no significant correlation between the resistance to treatment and the duration of the symptoms ( $\mathrm{r}=0.4597)$. Sixty-one of 72 patients $(84.7 \%)$ received one month of orthosis and oral/local medication and they were all healed. The remaining 11 patients with persistent pain received additional steroid injections. The mean age was 46.72 years at the injection group, and 10 of these 11 were female. Two female patients from these 11 resistant cases underwent surgical decompression.

Conclusion: In conclusion, our study also supported the self-limiting clinical feature of de Quervain's disease Most of the patients have satisfactory results with conservative treatment or corticosteroid injections if needed Most of the patients who needed corticosteroid injections in addition to splint use were female; therefore, the female patients should be informed in this aspect.

Keywords: De Quervain, Conservative management, Failure
\end{abstract}

\section{Öz}

Amaç: Birinci dorsal kompartmanın tenosinoviti olan de Quervain hastalığı sıklıkla konservatif olarak tedavi edilebilen bir antitedir. Bu çalışmamızda konservatif tedavi başarısını etkileyen parametreleri tartışmayı amaçladık.

Yöntemler: Mart 2014- Aralık 2016 tarihleri arasında el bileği radial stiloidde lokalize ağrı ile polikliniğimize başvuran ve de Quervain tanısı alan hastaların verilerine ulaşıldı. Ulaşılan 84 hastadan, başvuru öncesinde dıs merkezde müdahale edilen veya enjeksiyon yapılan, detaylı anamnezine ulaşılamayan ve ikinci kontrole gelmeyen 12'si çalışma dışı bırakıldı. Toplam 72 de Quervain hastası çalışmamıza dahil edildi. Hastaların yaşları, cinsiyetleri, semptomatik periyodun uzunluğu, travma anamnezi, başvurunun yapıldığı mevsim ve cerrahi gereksinimi sorgulandi.

Bulgular: Hasta grubu yaş ortalaması 42,24 (aralık 16-66) yıl olarak saptandı. Hastalardan 58'i kadın (\%80.6) ve 14'ü erkekti $(\% 19,4)$. Başvuru öncesi ortalama semptomatik periyodun 2,2 (aralık 1-12) ay olduğu görüldü. Bu periyodun uzunluğu ile tedaviye direnç arasında anlamlı ilişki saptanmadı $(r=0,4597) .72$ hastanın 61'inin $(\% 84,7)$ bir aylık istirahat ateli ve oral ve topikal antienflamatuar tedavi ile iyileştiği saptandı. Diğer 11 hastanın semptomlarının devam ettiği görüldü ve tamamına lokal kortikosteroid enjeksiyonu yapıldı. Enjeksiyon ihtiyac duyulan hastaların 10'unun kadın olduğu ve cerrahi tedaviye ihtiyaç duyan hastaların tamamının kadın olduğ görüldü. Enjeksiyon grubunun yaş ortalaması 46,72 yıl olarak saptandı. Takip eden kontrollerde bu 11 hastanın ikisinin enjeksiyona rağmen semptomlarda gerileme olmadığı ve cerrahi dekompresyon yapıldığı saptandı.

Sonuç: Çalışmamız de Quervain hastalığının kendini sınırlayıcı niteliğini teyit etmektedir. Hastaların çoğunluğu konservatif tedavi ya da kortikosteroid enjeksiyonu ile tedavi edilebilmektedir. Başvuran hastamız kadınsa medikal tedavi ve atele ilave olarak enjeksiyon tedavisi gerekebileceği hastaya anlatılmalıdır.

Anahtar Kelimeler: De Quervain, Konservatif tedavi, Başarısızlık
${ }^{1}$ Lutfiye Nuri Burat State Hospital, Orthopedics and Traumatology Clinic, Istanbul, Turkey

2 Gelisim University, Vocational School of Health Sciences, Department of Phusical Therapy and Rehabilitation, Istanbul, Turkey

3 Gelisim University, Vocational School of Health Sciences, Department of Orthosis and Prosthesis, Istanbul, Turkey

+ Medeniyet University, Goztepe Education and Research Hospital, Department of Plastic and Reconstructive Surgery, Istanbul, Turkey

Ethics Committee Approval: The study was approved by the local ethical authority (Istanbul Lutfiye Nuri Burat State Hospital, 2018/62560444929).

Etik Kurul Onayı: İstanbul Lütfiye Nuri Burat Devlet Hastanesi, 2018/62560444-929 kayit numarası ile etik kurul onayı alınmıştır.

Conflict of Interest: No conflict of interest was declared by the authors.

Çıkar Çatışması: Yazarlar çıkar çatışması bildirmemişlerdir.

Financial Disclosure: The authors declared that this case has received no financial support. Finansal Finansal Destek: Yazarlar bu olgu için finansal destek almadıklarını beyan etmişlerdir.

Geliș Tarihi / Received: 22.01.2018 Kabul Tarihi / Accepted: 26.02.2018 Yayın Tarihi / Published: 02.03.2018

Sorumlu yazar / Corresponding author

Hasan Hüseyin Ceylan

Adres/Address: Lütfiye Nuri Burat Devlet Hastanesi, 50.Y1l mahallesi, 2016 sokak, 34265,

Sultangazi, İstanbul, Türkiye.

Tel: 05306966045

e-posta:drhhc@yahoo.com

Copyright (C) ACEM 


\section{Introduction}

Stenosing tenosynovitis of the first dorsal compartment of the wrist, which includes two tendons, is also known as de Quervain's disease. It is a well-known pathological condition of the wrist and its incidence is estimated between 0.94 to 6.3 per 1000 person [1,2]. The pain may be provoked by ulnar deviation of the wrist and abduction of the first metacarpophalangeal joint in flexion, which is called as Finkelstein's test [3]. The clinical condition is de Quervain syndrome (DS).

The exact etiology of the disease has not been well described yet. Literature focused on overuse of the wrist as the major etiologic factor for the disease [3]. Repetitive ulnar deviation while the metacarpophalangeal joint of the thumb is in flexion, like typing, lifting etc., is considered to result such clinical problem [4]. Cumulative trauma from repetitive strain is triggering the pathologic changes. The pathophysiology of the disease is thought to be thickening and stenosing of the synovial sheath of the first extensor dorsal compartment due to repetitive trauma or overuse, which contains the extensor pollicis brevis (EPB) and abductor pollicis longus (APL) tendons [3]. This stenosing causes impaired gliding of the APL and EPB tendons due to narrowing of the first dorsal compartment and thickening of the extensor retinaculum. Pathological fibroblastic response of the tendon vagina was also shown before [5].

The release of the first dorsal compartment is the last method to solve the problem surgically [6]. Most surgeons recommend conservative management including splinting and nonsteroidal anti-inflammatory drugs as the first line treatment [7]. In case of failure of conservative treatment, a single dose of local corticosteroid administration may be helpful for relieving the pain up to $83 \%$ of the cases [8]. Additional conservative management modalities include acupuncture, platelet-rich plasma injection, hyaluranic acid injection, and ultrasound $[9,10]$. Many studies on the effectiveness of conservative treatment were reported in current literature $[6,7,11]$. Additional to splinting and medication, occupational therapy was considered to be important for the success of the conservative treatment. This includes patient education and modification of the daily activities that may provoke the pathology $[7,12,13]$. However, factors affecting the success of conservative treatment of disease are not well described. Purpose of this study is to figure out the factors affecting the success of conservative treatment for DS.

\section{Material and methods}

The design of our study was a retrospective database evaluation. The study was performed in a district hospital's outpatient service. After approval of the local ethical authority (Istanbul Lutfiye Nuri Burat State Hospital, 2018/62560444929), patient records with a diagnosis of DS between March 2014 and December 2016 were evaluated and presented in this paper.

The patients with a diagnosis of DS were identified from electronic hospital medical archiving system according to International Classification of Diseases (ICD) coding system, as radial styloid tenosynovitis (M65.4). Then, patients' files were searched for exact diagnosis and inclusion criteria. On the other hand, the term 'quervain' was searched from all electronic files of the orthopedic patients. The medical history of each patient was evaluated. The patients with a diagnosis of DS based on the tenderness and/or swelling on the radial styloid and the first dorsal compartments, with a positive Finkelstein test were determined by two separate surgeons. Patients with a history of previous history of interventions, suspicious diagnosis because of unavailable or incomplete patient's data, loss of follow up after initial out-patient admission, previously receiving a corticosteroid injection or different conservative treatment modalities in different centers were excluded.

All patients were evaluated in terms of accurate diagnosis and prescribed with anti-inflammatory medication and splint at the first admission. Both of our surgeons at the institution routinely called the patients after the 4 th months of the treatment in their clinical practice to evaluate the efficacy of the treatment. The conservative management was considered to fail in case of unresponsiveness to the four weeks of splint and drug usage.

Patients were evaluated according to age and sex, reported symptomatic period before the admission, previous history of a trauma around the wrist, and need of injection and surgical release in addition to the conservative management.

Statistical analysis

All statistics were performed using SPSS 20.0 for Windows (SPSS Statistics for Windows, Version 20.0, IBM Corp., Armonk, NY, USA). Continuous variables were expressed as mean \pm standard deviation (SD). Categorical variables were expressed as frequencies. Pearson correlation test was used to evaluate the correlation between the length of preadmission symptomatic period and treatment resistance. The differences were considered statistically significant if the $p$ value was equal to or less than 0.05 .

\section{Results}

Among 84 patients with a diagnosis of DS found in the electronic database, six were excluded due to a history of previous interventions, like splinting or injection, in other clinics. Four patients were also excluded due to lack of detailed anamnesis records. Two patients were also excluded due to loss of follow up after the first admission. Therefore, a total of 72 patients with DS were included in our study.

The mean age of the patient group was 42.24 (range 1666) years. Of the 72 patients, $58(80.6 \%)$ were female and 14 patients $(19.4 \%)$ were male, the disease affected females more than males. The mean symptomatic period before the hospital admission was 2.2 (range 1-12) months. There was no significant relationship between the length of this period and treatment resistance (Pearson Correlation test, $r=0.4597$ ). Sixty one of 72 patients $(84.7 \%)$ were recovered at 1 -month rest and oral and topical anti-inflammatory therapy. The other 11 patients $(15.3 \%)$ continued to have symptoms despite splinting and medical treatment and a local corticosteroid (Diprospan ${ }^{\circledR}$, injectable ampoule, betamethasone dipropionate and betamethasone sodium phosphate, Merck Sharp \& Dohme, Istanbul, Turkey) injection were made. It was seen that 10 of the patients who needed injection were female and all of the patients who needed surgical treatment were female. The mean age of the injection group was 46.72 years old. In follow-up controls, two of these 11 patients were found to have no symptom relief despite the injection, and surgical decompression was performed. Only one of the patients had a history of trauma that healed with conservative treatment in the first month of admission.

\section{Discussion}

Controversies about the main pathophysiological mechanism of DS are going on. Some authors suggest acute inflammation as the main pathophysiology, in contrast, the others point to myxoid degeneration [3,14-16]. For these reasons, some authors suggest the use of "tendinosis" instead of tendinitis. Repetitive tension on APL and EPB tendons due to overuse, or any other triggering mechanism result with fibroblastic response of the tendon vagina [5]. In our study cohort, all patients had a history of overuse, and only one patient reported a previous trauma. 
Despite all possible pathological mechanisms, the clinical presentation is almost the same. A pain around the radial side of the wrist, which may be aggravated with forced ulnar deviation of the wrist joint [3]. This is called as Finkelstein test in literature. All of our patients had positive sign of Finkelstein test.

DS is also suggested as a self-limiting condition in current studies [17]. So overtreatment is unnecessary, and simple way of local injection seems sufficient for treatment. In our cohort, nearly $85 \%$ of patients' complaints resolved with a one month of splinting and anti-inflammatory medication. In our cohort, 11 of $72(15.3 \%)$ had persistent pain after a month of splinting and medication, and undergone local injection and it was effective in nine of these 11 cases.

Menendez et al [18] compared the effect of fulltime vs. desired time use of splinting for DS in a randomized controlled study, and they couldn't find a difference in symptom relief between two groups. We didn't compare this difference in our cohort.

Corticosteroid injection alone resulted in better outcomes compared with other conservative treatment modalities in terms of early pain relief and activity limitation [14, 19]. Mardani-Kivi et al [20] also favored corticosteroid injection plus splinting in terms of the success of treatment and functional outcomes, compared to corticosteroid injection alone. In contrast to corticosteroid injection studies, some authors pointed the adverse effects of corticosteroid injections such as atrophy of subcutaneous tissue, an increase of blood glucose levels in type 1 diabetic patients and local flare reactions [21, 22]. Other injection methods like platelet-rich plasma or hyaluronic acid were also reported, but they are not so practical and costeffective, compared to corticosteroid [9]. In our patients, we used corticosteroids routinely and did not have any related complication.

Surgical release of the first dorsal compartment for treatment of DS is mainly indicated in patients unresponsive to corticosteroid injections and having persistent symptoms more than six months despite conservative treatment methods [16, 23]. The surgical release resulted in satisfactory clinical outcomes with minimal morbidity in general [17]. In our cohort, only two $(2.7 \%)$ cases were resistant to conservative treatment and local injection and treated with surgical decompression.

Some factors may decrease the efficacy of conservative treatment. Patients with a lower psychosocial well-being response were reported to perceive higher levels of dissatisfaction from conservative treatment [8]. Ilyas [7] stated that splinting is an essential part of successful conservative management, and decreased cooperation of the patient to splinting may decrease the success. Parents with a baby should be warned to limit lifting periods of their babies during treatment [7]. Female sex and increased age are other factors that inversely correlated with the success of conservative treatment [3]. Our study cohort pointed that the majority of DS patients were women $(80.6 \%)$ and 10 of 11 patients in dissatisfaction group $(15.3 \%)$ was women, that was similar to literature findings. These patients were unresponsive to splinting and antiinflammatory treatment of four weeks. All undergone corticosteroid injection and all healed except two cases. Both of these patients who had undergone surgical intervention were also female. The mean age of corticosteroid injection group was higher than conservatively treated patient group. Previous studies pointed longer duration of the symptoms and need for a local corticosteroid injection [24]. In our cohort, we could not find any relation between symptom duration and persistence of pain.

Our study has certain limitations. First of all, the number of evaluated patients was very low for a common conclusion. Factors like occupation, daily habits, and concomitant medical conditions like diabetes may also interfere with the success of treatment. However, we could not access to these details in our digital database. There may be some individual differences on the preference of injection types and styles, and this detail may change the results.

In conclusion, our study also supported the self-limiting clinical feature of DS. Most of DS patients have satisfactory results with conservative treatment or corticosteroid if needed. Female patients should be kept in mind for the possible resistance to conservative management and need of corticosteroid injection in addition to splint use.

\section{References}

1. Roquelaure Y, Ha C, Leclerc A, Touranchet A, Sauteron M, Melchior $\mathrm{M}$, et al. Epidemiologic surveillance of upper-extremity musculoskeletal disorders in the working population. Arthritis Rheum. 2006;55:765-78.

2. Wolf JM, Sturdivant RX, Owens BD. Incidence of de Quervain's tenosynovitis in a young, active population. J Hand Surg Am. 2009;34:112-5.

3. Wolfe SW, Hotchkiss RN, Pederson WC, Kozin SH, Cohen MS, editors. Green's operative hand surgery. 7th ed. Wolfe SW, Tendinopathy. Pages: 1916-9. Philadelphia: Elsevier; 2017.

4. Robinson BS. Rehabilitation of a cellist after surgery for de Quervain's tenosynovitis and intersection syndrome. Med Probl Performing Artists. 2003;18:106-12.

5. Patel KR, Tadisina KK, Gonzalez MH. De Quervain's Disease. Eplasty. 2013;13:ic52.

6. Goel R, Abzug JM. de Quervain's tenosynovitis: a review of the rehabilitative options. Hand (N Y). 2015;10:1-5.

7. Ilyas A. Nonsurgical treatment of de Quervain's tenosynovitis. J Hand Surg. 2009;34A:928-9.

8. Kazmers NH, Liu TC, Gordon JA, Bozentka DJ, Steinberg DR, Gray BL. Patient and Disease-Specific Factors Associated With Operative Management of de Quervain Tendinopathy. J Hand Surg Am. 2017;42:931.e1-931.e7.

9. Rowland P, Phelan N, Gardiner S, Linton KN, Galvin R. The Effectiveness of Corticosteroid Injection for De Quervain's Stenosing Tenosynovitis (DQST): A Systematic Review and Meta-Analysis. Open Orthop J. 2015;9:437-44.

10. Hartzell TL, Rubenstein R, Herman M. Therapeutic modalities an updated review for the hand surgeon. J Hand Surg. 2013;37A:597621

11. Avci S, Yilmaz C, Sayli U. Comparison of nonsurgical treatment measures for de Quervain's disease of pregnancy and lactation. J Hand Surg. 2002;27: 322-4.

12. Ilyas AM, Ast M, Schaffer AA, Thoder J. De Quervain tenosynovitis of the wrist. J Am Acad Orthop Surg. 2007;15:757-64.

13. Jaworski CA, Krause M, Brown J. Rehabilitation of the wrist and hand following sports injury. Clin Sports Med. 2010;29:61-80

14. Peters-Veluthamaningal C, Winters JC, Groenier KH, MeyboomDeJong B. Randomised controlled trial of local corticosteroid injections for de Quervain's tenosynovitis in general practice. BMC Musculoskelet Disord. 2009;10:131.

15. Weiss AP, Akelman E, Tabatabai M. Treatment of de Quervain's disease. J Hand Surg Am. 1994;19:595-8.

16. Witt J, Pess G, Gelberman RH. Treatment of de Quervain tenosynovitis. A prospective study of the results of injection of steroids and immobilization in a splint. J Bone Joint Surg Am. 1991;73:219-22.

17. Lee HJ, Kim PT, Aminata IW, Hong HP, Yoon JP, Jeon IH. Surgical release of the first extensor compartment for refractory de Quervain's tenosynovitis: surgical findings and functional evaluation using DASH scores. Clin Orthop Surg. 2014;6:405-9.

18. Menendez ME, Thornton E, Kent S, Kalajian T, Ring D. A prospective randomized clinical trial of prescription of full-time versus as-desired splint wear for de Quervain tendinopathy. Int Orthop. 2015;39:1563-9.

19. Makarawung DJ, Becker SJ, Bekkers S, Ring D. Disability and pain after cortisone versus placebo injection for trapeziometacarpal arthrosis and de Quervain syndrome. Hand (N Y). 2013;8:375-81.

20. Mardani-Kivi M, Karimi Mobarakeh M, Bahrami F, HashemiMotlagh K, Saheb-Ekhtiari K, Akhoondzadeh N. Corticosteroid 
injection with or without thumb spica cast for de Quervain tenosynovitis. J Hand Surg Am. 2014;39:37-41.

21. Goldfarb CA, Gelberman RH, McKeon K, Chia B, Boyer MI. Extraarticular steroid injection: early patient response and the incidence of flare reaction. J Hand Surg Am. 2007;32:1513-20.

22. Stepan JG, London DA, Boyer MI, Calfee RP. Blood glucose levels in diabetic patients following corticosteroid injections into the hand and wrist. J Hand Surg Am. 2014;39:706-12.

23. Capasso G, Testa V, Maffulli N, Turco G, Piluso G. Surgical release of de Quervain's stenosing tenosynovitis postpartum: can it wait? Int Orthop. 2002;26:23-5.

24. McKenzie JM. Conservative treatment of de Quervain's disease. $\mathrm{Br}$ Med J. 1972;4:659-60. 